\title{
Implementasi Kepatuhan Terhadap Prinsip Syariah Melalui Penggunaan Polis Standar Dalam Asuransi Syariah
}

\author{
Lastuti Abubakar, C. Sukmadilaga \\ Fakultas Hukum Universitas Padjadjaran \\ lastuti62abubakar@gmail.com
}

\begin{abstract}
One of the strategic issues of the slow growth of the Sharia Insurance industry is the availability of human resources that controls the Sharia Insurance, which affects the low understanding of the community on the differences between sharia and conventional insurance, especially in relation to the contracts used and contributions as a tabarru 'fund different from premiums. Based on these conditions, this study examines and analyzes the implementation of Sharia principles through the use of sharia insurance policy standards. This research is normative and analytical descriptive research. Normative legal research in the form of research to find the law of a case by describing and analyzing data related to implementation of compliance with sharia principles. The results show that compliance with sharia principles is a public expectation. The standard policy that contains the agreement between the Takaful company and the customer becomes the means to ensure compliance with sharia compliance by elaborating the principles of sharia in the policy to be implemented. The fundamental difference in mechanisms between sharia and conventional insurance can be realized through a standard policy, with reference to the standard policy guidelines issued by the Indonesian Sharia Insurance Association (AASI).
\end{abstract}

\section{Keywords: compliance with sharia principles - policy standards}

\footnotetext{
Abstrak

Salah satu isu strategis lambatnya pertumbuhan industri asuransi syariah adalah ketersediaan sumber daya manusia yang menguasasi asuransi syariah, yang berdampak terhadap rendahnya pemahaman masyarakat terhadap perbedaan antara asuransi syariah dan konvensional, khususnya berkaitan dengan akad yang digunakan dan kontribusi sebagai dana tabarru' yang berbeda dengan premi. Berkaitan dengan itu, penelitian ini mengkaji dan menganalisis implementasi prinsip-prinsip syariah melalui penggunaan polis standar asuransi syariah. Penelitian ini merupakan penelitian hukum normatif dan bersifat deskriptif analitis. Penelitian hukum normatif berupa penelitian untuk menemukan hukum suatu perkara dengan menggambarkan dan menganalisis data terkait implementasi kepatuhan terhadap prinsip syariah. Hasil penelitian menunjukkan bahwa kepatuhan terhadap prinsip syariah ini merupakan ekspektasi masyarakat. Polis standar yang berisi kesepakatan antara perusahaan asuransi syariah dan nasabah menjadi sarana
} 
untuk memastikan kepatuhan terhadap prinsip syariah (sharia compliance) dengan cara mengelaborasi prinsip-prinsip syariah dalam polis untuk diimplementasikan. Perbedaan mekanisme yang mendasar antara asuransi syariah dan konvensional dapat diwujudkan melalui polis standar, dengan mengacu pada pedoman standar polis yang dikeluarkan oleh Asosiasi Asuransi Syariah Indonesia (AASI).

\section{Kata Kunci: kepatuhan terhadap prinsip syariah- standar polis}

\section{Pendahuluan}

Berlakunya Undang-undang Nomor 40 Tahun 2014 Tentang Perasuransian mengubah peta regulasi industri asuransi di Indonesia. Undang-undang ini secara tegas mengatur keberadaan asuransi syariah berdampingan dengan asuransi konvensional. Dengan demikian, eksistensi asuransi syariah sebagai alternatif asuransi yang dapat dipilih oleh masyarakat telah mempunyai landasan hukum, walaupun belum dirasakan optimal mengingat pengaturan asuransi syariah belum terintegrasi dalam suatu perundang-undangan yang khusus mengatur tentang asuransi syariah, sebagaimana halnya regulasi perbankan syariah. (Perbankan Syariah diatur dalam perundangundangan tersendiri, yaitu UU Nomor 21 Tahun 2008 Tentang Perbankan Syariah ). Implikasi yuridis dari pengaturan dalam UU Nomor 40 Tahun 2014 Tentang Perasuransian tersebut adalah terjadinya dualisme hukum asuransi di Indonesia, yakni berlaku lebih dari sistem hukum untuk mengatur bidang asuransi, yaitu hukum asuransi konvensional dan hukum asuransi syariah.

Pembaruan hukum perasuransian ini merupakan langkah antisipatif sekaligus memanfaatkan peluang untuk mengembangkan industri asuransi syariah di Indonesia sejalan dengan perkembangan industri keuangan syariah global. Sebagai bagian dari institusi keuangan syariah, pertumbuhan dan perkembangan industri asuransi syariah secara global menunjukkan pertumbuhan dan perkembangan yang positif, khususnya di Negara-negara 
dengan pangsa pasar kunci, yaitu Saudi Arabia, UAE dan Malaysia. Berdasarkan analisa Ernst \& Young, salah satu perusahaan penyedia jasa profesional dunia, pertumbuhan pasar asuransi syariah (takaful) global berkisar $14 \%$ pada tahun 2014 , dan pada tahun 2017, industri asuransi syariah global dapat berkontribusi hingga mencapai lebih dari US \$20 Triliun (Ernst \& Young, 2014:3). Di tingkat regional, pasar terbesar asuransi syariah yakni Saudi Arabia dan Malaysia menyumbang hampir $44 \%$ dari kontribusi total asuransi syariah global. (Malaysia International Islamic Financial Centre, 2014:1). Asuransi syariah di Indonesia pun memperlihatkan perkembangan yang positif, dan berkontribusi sebesar 15-20 \% terhadap pertumbuhan ekonomi nasional (Lihat hasil penelitian Lastuti Abubakar, dkk. Urgensi Sertifikasi Kelembagaan Takaful dalam Rangka Perlindungan Nasabah, 2014). Berdasarkan data yang dikeluarkan oleh AASI market share (pangsa pasar) asuransi syariah terhadap industri asuransi sebesar 5, $25 \%$, dengan kontribusi donasi sebesar 176, 796.12 Miliar. Secara keseluruhan, jumlah perusahaan /unit asuransi syariah pada tahun 2016 mengalami pertumbuhan sebagaimana dapat dilihat dari tabel di bawah ini :

Tabel 1 . Jumlah Unit dan Perusahaan Asuransi Syariah Q1 2016

\begin{tabular}{llcc}
\hline No & \multicolumn{1}{c}{ Keterangan } & Q1 2016 & Q1 2015 \\
\hline $\mathbf{1}$ & Perusahaan Asuransi Jiwa Syariah & 5 & 3 \\
\hline $\mathbf{2}$ & Perusahaan Asuransi Umum Syariah & 4 & 2 \\
\hline $\mathbf{3}$ & $\begin{array}{l}\text { Unit Syariah Perusahaan Asuransi } \\
\text { Jiwa }\end{array}$ & 19 & 18 \\
\hline $\mathbf{4}$ & $\begin{array}{l}\text { Unit Syariah Perusahaan Asuransi } \\
\text { Umum }\end{array}$ & 24 & 23 \\
\hline $\mathbf{5}$ & $\begin{array}{l}\text { Unit Syariah } \\
\text { Reasuransi }\end{array}$ & 3 & 3 \\
\hline & POTAL & 55 & 49 \\
\hline
\end{tabular}

Sumber : AASI, Data Bisnis Asuransi dan Re-asuransi Syariah Q1 2016. 
Berdasarkan data pada tabel 1 dapat dilihat bahwa pelaku usaha asuransi syariah sebagian besar masih berbentuk unit usaha syariah sebagai bagian dari perusahaan asuransi konvensional, yakni berjumlah 46 Unit usaha, sedangkan yang berbentuk perusahaan mandiri hanya berjumlah 9 perusahaan. Kondisi ini mempengaruhi pengambilan kebijakan dan regulasi asuransi syariah di Indonesia, khususnya gagasan untuk mengusulkan dibentuknya undang-undang khusus tentang asuransi syariah.

Selanjutnya, pertumbuhan dan kontribusi asuransi asuransi syariah dapat dilihat dari tabeltabel di bawah ini :

Tabel 2. Pertumbuhan Aset, Investasi, Kontribusi dan Klaim Asuransi Syariah Triwulan IV 2015

Dalam Milyar

\begin{tabular}{llll}
\hline Indikator & Q1 2016 & Q1 2015 & Pertumbuhan \\
\hline Aset & $28,967.00$ & $23,803.00$ & $21,69 \%$ \\
\hline investasi & $25,726.00$ & $20,808.00$ & $23,64 \%$ \\
\hline Kontribusi Bruto & $2,753.00$ & $2,497.00$ & $10.25 \%$ \\
\hline Klaim Bruto & 895.00 & 863.00 & $3,71 \%$ \\
\hline
\end{tabular}

Sumber : AASI 2016

Tabel 3. Pendapatan Kontribusi thn 2016 dan Pertumbuhannya Dalam Milyar

\begin{tabular}{|c|c|c|c|c|}
\hline Indikator & & Q1 2016 & Q1 2015 & Pertumbuhan \\
\hline Asuransi & Jiwa & 2,168 & 2,119 & $2,31 \%$ \\
\hline Syariah & & & & \\
\hline
\end{tabular}

\begin{tabular}{llllll}
\hline Asuransi & Umum & $\&$ & 585 & 378 & $54,76 \%$
\end{tabular}

Reasuransi Syariah

\begin{tabular}{llll}
\hline Jumlah Asuransi \& & 2,753 & 2,497 & $10,25 \%$ \\
Reasuransi Syariah & & \\
\hline
\end{tabular}

\begin{tabular}{llr}
\hline Sumber: AASI 2016 & & \\
Pertumbuhan aset, investasi & syariah mencatat pertumbuhan \\
dan kontribusi industri asuransi & walaupun terjadi penurunan
\end{tabular}


dibanding tahun sebelumnya, ini mengingat asuransi syariah dengan mencatat pertumbuhan bertumpu pada prinsip syariah, aset asuransi syariah sebesar yang harus diakomodasikan dalam $21,69 \%$ dan investasi sebesar peraturan perundang-undangan. 23,64 \%. Pertumbuhan Otoritas Jasa Keuangan kontribusi pada tahun 2016 sebesar 10,25 \% memperlihatkan kenaikan apabila dibandingkan dengan tahun 2015 yang hanya mencatatkan pertumbuhan tidak lebih dari $5 \%$.

Berdasarkan data di atas, dapat dilihat bahwa industri asuransi syariah sebagai bagian dari sektor jasa keuangan menunjukkan perkembangan dan kontribusi positif dalam aktivitas ekonomi Indonesia. Ke depan, potensi pengembangan asuransi syariah di Indonesia akan semakin meningkat seiring tingkat pemahaman dan kebutuhan masyarakat terhadap asuransi syariah. Selain itu, sumber daya insani asuransi syariah semakin professional dengan kewajiban sertifikasi (Lastuti Abubakar, 2014).

Kesiapan regulasi merupakan salah satu faktor pendukung untuk dapat mendorong perkembangan asuransi syariah di Indonesia. Hal menyadari pentingnya regulasi bagi setiap industri, termasuk asuransi syariah agar dapat mendorong perkembangan insdustri secara cepat, tumbuh sehat dan akuntabel. (Otoritas Jasa Keuangan, Roadmap INB Syariah 2015-2019;37).

Selain isu regulasi, kesiapan sumber daya insani merupakan salah satu isu strategis dalam pengembangan industri keuangan syariah, termasuk asuransi syariah, mengingat sumber daya insani inilah yang akan menjadi penggerak dalam melakukan inovasi produk, peningkatan kualitas proses internal perusahaan dan layanan kepada peserta. (Otoritas Jasa Keuangan Syariah Roadmap IKNB Syariah 2015-2019:39) Ke dua isu strategis ini, memerlukan dukungan baik dari pemerintah, dalam hal ini Otoritas Jasa Keuangan maupun dari Asosiasi Asuransi Syariah (AASI). 
Asosiasi telah melakukan upayaupaya untuk memastikan kepatuhan terhadap prinsip syariah melalui peningkatan pengetahuan sumber daya insani dengan melaksanakan program sertifikasi agen. Selain itu, asosiasi juga telah menerbitkan pedoman polis asuransi jiwa dan asuransi umum berdasarkan prinsip syariah sebagai pelaksanaan dari Peraturan Menteri Keuangan Nomor 18/PMK.010/2010 sebagaimana telah diubah dengan Peraturan Menteri Keuangan Nomor 227/PMK.010/2012 tentang Perubahan atas Peraturan Menteri Keuangan Tentang Penerapan Prinsip Dasar Penyelenggaraan Usaha Asuransi dan Usaha Reasuransi dengan Prinsip Syariah.

Pedoman ini bertujuan untuk menjadi panduan bagi perusahaan asuransi syariah untuk mengakomodasikan prinsipprinsip syariah ke dalam polis asuransi. Sosialisasi pedoman polis asuransi syariah telah dilakukan pada bulan Mei 2014 kepada seluruh perusahaan asuransi syariah. Diharapkan mulai Januari 2015 seluruh perusahaan asuransi syariah sudah memiliki polis standar asuransi jiwa syariah dan asuransi umum syariah yang sesuai dengan pedoman polis yang dikeluarkan oleh AASI. Salah satu kendala yang dihadapi industri asuransi syariah di Indonesia dalam meningkatkan pangsa pasar adalah memberikan pemahaman tentang asuransi syariah. Direktorat Institusi Keuangan Non Bank (IKNB) Syariah - Otoritas Jasa Keuangan (OJK) mengakui sulitnya mengedukasi masyarakat terkait aktivitas asuransi syariah ini (Hasil wawancara dengan Direktur IKNB Syariah OJK, Bapak Muchlasin pada tanggal 23 Mei 2014). Kesulitan ini muncul antara lain pemahaman asuransi syariah yang kadangkala ditafsirkan dengan mengacu pada mekanisme asuransi konvensional atau pemahaman yang tidak utuh terhadap prinsip syariah, sehingga menimbulkan keraguan bagi masyarakat terhadap perbedaan asuransi syariah dan konvensional. Contoh kesalahpahaman yang 
lazim ditemukan adalah anggapan bahwa kontribusi dalam asuransi syariah disamakan dengan premi dalam asuransi konvensional, padahal secara yuridis kontribusi yang diserahkan oleh peserta kepada perusahaan asuransi syariah merupakan pemberian dana dari peserta berdasarkan akad tabarru (akad hibah) untuk tujuan tolong menolong diantara para Peserta yang tidak bersifat dan bukan untuk tujuan komersial yang disebut dengan Dana Tabarru'(Lihat Pedoman Polis Asuransi Jiwa Berdasarkan Prinsip Syariah, Asosiasi Asuransi Syariah Indonesia, 2014). Dana Tabarru ini selanjutnya dikelola oleh perusahaan asuransi syariah untuk kepentingan Para Peserta, sesuai tujuan asuransi syariah. Menyadari pentingnya polis standar sebagai salah satu upaya untuk memastikan bahwa hubungan hukum antara perusahan asuransi syariah dan para Peserta berdiri diatas landasan prinsip syariah, maka substansi polis syariah seharusnya merepresentasikan prinsip-prinsip syariah sehingga memberikan kepastian dan jaminan bagi Peserta bahwa produk dan mekanisme asuransi syariah patuh kepada prinsip syariah. Berdasarkan latar belakang tersebut, penelitian ini bermaksud mengkaji dan menganalisis bagaimana implementasi prinsipprinsip syariah melalui penggunaan polis standar asuransi syariah.

\section{Metode Penelitian}

Penelitian ini merupakan Penelitian Hukum Normatif dan bersifat Deskriptif Analitis. Penelitian Hukum Normatif berupa penelitian untuk menemukan hukum In Concreto, yaitu penelitian untuk menemukan hukum bagi suatu perkara in concreto (Ronny Hanitijo Soemitro, 1988:22). Metode penelitian yang digunakan bersifat deskriptif analitis yaitu menggambarkan dan menganalisis data yang diperoleh berupa data sekunder dan didukung oleh data primer mengenai berbagai masalah yang berkaitan dengan implemntasi kepatuhan terhadap prinsip syariah melalui 
penggunaan polis standar dalam praktik asuransi syariah.

\section{Hasil Penelitian Dan Analisa}

a) Polis Sebagai Bukti Adanya Perjanjian Antara Perusahaan dan Peserta dalam Aktivitas Asuransi Syariah.

Pasal 1 Angka 2 UU Nomor 40 Tahun 2014 Tentang Perasuransian mengatur bahwa Asuransi Syariah adalah kumpulan perjanjian, yang terdiri atas perjanjian antara perusahaan asuransi syariah dan pemegang polis, dan perjanjian di antara para pemegang polis, dalam rangka pengelolaan kontribusi berdasarkan prinsip syariah guna saling menolong dan melindungi dengan cara : (1) Memberikan penggantian kepada para peserta atau pemegang polis karena kerugian, kerusakan, biaya yang timbul, kehilangan keuntungan, atau tanggung jawab hukum kepada pihak ketiga yang mungkin diderita peserta atau pemegang polis karena terjadi peristiwa yang tidak pasti; atau (2) Memberikan pembayaran yang didasarkan pada meninggalnya peserta atau pembayaran yang didasarkan pada hidupnya peserta dengan manfaat yang besarnya telah ditetapkan dan/atau didasarkan pada hasil pengelolaan dana.

\section{Undang-Undang}

Perasuransian menggunakan istilah pemegang polis, namun tidak menjelaskan apa yang dimaksud dengan polis. Pasal 1 Angka 22 Undang-undang Perasuransian mengatur tentang siapa yang dimaksud dengan pemegang polis, yaitu Pihak yang mengikatkan diri berdasarkan perjanjian dengan Peursahaan Asuransi, Perusahaan Asuransi syariah, perusahaan reasuransi, atau perusahaan reasuransi syariah untuk mendapatkan perlindungan atau pengelolaan atas risiko bagi dirinya, tertanggung atau peserta lainnya. Selanjutnya, menurut Pasal 1 Angka 3 UU Perasuransian, yang dimaksud dengan prinsip syariah adalah prinsip hukum Islam dalam kegiatan perasuransian berdasarkan Fatwa yang dikeluarkan oleh lembaga yang memiliki kewenangan dalam penetapan Fatwa di bidang syariah (Lembaga yang diberi 
kewenangan menerbitkan Fatwa adalah Dewan Syariah Nasional (DSN) - Majelis Ulama Indonesia ). Dengan demikian, dapat disimpulkan bahwa dasar hubungan hukum antara perusahaan dan Peserta adalah perjanjian yang dituangkan dalam polis, yang secara khusus mengatur tentang kontribusi yang harus diserahkan oleh Peserta kepada Perusahaan (dana tabarru'), selanjutnya akan dikelola untuk kepentingan seluruh Peserta berdasarkan prinsip syariah guna saling menolong. Pasal 26 UU Perasuransian menyebutkan polis sebagai cakupan standar perilaku usaha yang wajib dipenuhi oleh perusahaan asuransi, termasuk asuransi syariah. Selanjutnya, kewajiban menerbitkan polis ini selanjutnya diatur dalam POJK Nomor 23/POJK.05/2015 tentang Produk Asuransi dan Pemasaran Produk Asuransi. Di dalam POJK inilah definisi polis asuransi diatur dalam Pasal 1 Angka 6, yaitu "akta perjanjian asuransi atau dokumen lain yang dipersamakan dengan akta perjanjian asuransi, serta dokumen lain yang merupakan satu kesatuan yang tidak terpisahkan dengan perjanjian asuransi, yang dibuat secara tertulis dan memuat perjanjian antara pihak perusahaan asuransi dan pemegang polis".

Menurut hemat penulis, definisi polis ini agak berlebihan karena menyebutkan bahwa polis adalah akta perjanjian, dan memuat perjanjian antara pihak perusahaan asuransi dan pemegang polis. Mungkin yang dimaksud pembuat peraturan adalah akta perjanjian yang memuat kesepakatan diantara para pihak. Sebelum UU Perasuransian dan POJK, kewajiban menerbitkan polis sudah diatur dalam Pasal 255 Kitab Undangundang Hukum Dagang (KUHD), yang mengatur bahwa perjanjian asuransi harus dibuat secara tertulis dalam bentuk akta yang disebut polis. Peraturan Pemerintah Nomor 73 Tahun 1992 Tentang Penyelenggaraan Usaha Perasuransian (Peraturan Pemerintah ini telah mengalami beberapa kali perubahan, yang 
terakhir diubah dengan PP Nomor

81 Tahun 2008 tentang

Perubahan Ketiga Atas Peratuan

Pemerintah Nomor 73 Tahun

1992 Tentang Penyelenggaraan

Usaha Perasuransian) secara implisit mengakui bahwa bentuk perjanjian asuransi dituangkan dalam bentuk tertulis yang disebut polis. Hal ini dapat dilihat dalam Pasal 19 PP Nomor 73 Tahun 1992, bahwa "polis atau bentuk perjanjian asuransi dengan nama apapun, berikut lampiran yang merupakan kesatuan dengannya, tidak boleh mengandung kata-kata atau kalimat yang dapat menimbulkan penafsiran yang berbeda mengenai risiko yang ditutup asuransinya, kewajiban penanggung dan kewajiban tertanggung, atau mempersulit tertanggung mengurus haknya". Mengacu pada ke dua pengaturan di atas, maka dapat disimpulkan bahwa polis merupakan bentuk tertulis perjanjian asuransi. Berkaitan dengan format polis, tampaknya POJK mengadopsi apa yang sudah diatur dalam PP Nomor 73 Tahun 1992. Mengacu pada beberapa peratutan sebagimana telah diuraikan, maka polis wajib diterbitkan sebagai perjanjian tertulis yang memuat hak dan kewajiban baik perusahaan asuransi maupun pemegang polis.

Dalam praktik, polis adalah bukti tertulis yang dikeluarkan oleh perusahaan asuransi, baik konvensional maupun syariah kepada pihak yang menutup perjanjian asuransi dengan perusahaan asuransi. Dengan demikian, dalam aktivitas asuransi, polis mempunyai fungsi penting, antara lain : (1) bukti tertulis adanya hubungan hukum yang timbul dari perjanjian (akad) antara perusahaan asuransi, baik konvensional maupun syariah dengan para peserta, (2) dasar penentuan hak dan kewajiban para pihak, serta tanggung jawab yang harus dipikul ke dua belah pihak, (3) Khusus bagi asuransi syariah, polis memuat klausul-klausul sebagai implementasi dari prinsipprinsip syariah.

Dapat dikatakan bahwa fungsi utama polis adalah jaminan dan kepastian bagi perlindungan hukum terhadap ke dua belah 
pihak, baik perusahaan maupun peserta. Sebelum diterbitkannya pedoman polis standar oleh AASI, polis yang dikeluarkan oleh perusahaan asuransi syariah belum seragam. Secara khusus, pedoman polis asuransi syariah yang diterbitkan oleh AASI, akan mempermudah pelaku usaha asuransi syariah untuk menerjemahkan prinsip syariah ini ke dalam klausul polis secara tepat. Selain itu, diharapkan akan terdapat keseragaman pemahaman terhadap prinsip syariah, yang berguna untuk meminimalisasi perbedaan penafsiran terhadap prinsip syariah. Implementasi kepatuhan terhadap prinsip syariah (sharia compliance) ini pada gilirannya akan meningkatkan kepercayaan masyarakat terhadap aktivitas asuransi syariah. Dari perspektif hukum, kepatuhan terhadap prinsip syariah memberikan kepastian dan jaminan hukum bagi masyarakat pengguna jasa asuransi syariah. Selain pedoman polis yang diterbitkan oleh AASI, substansi polis asuransi syariah perlu memperhatikan tujuan asuransi syariah sebagaimana dirumuskan dalam Fatwa Dewan Syariah Nasional (DSN) Nomor 21/DSN-MUI/X/2001 Tentang Pedoman Umum Asuransi Syariah, bahwa yang dimaksud dengan asuransi syariah (ta'min, takaful atau tadhamun) adalah:

"Usaha saling melindungi dan tolong menolong diantara sejumlah orang/pihak melalui investasi dalam bentuk aset dan/atau tabarru' yang memberikan pola pengembalian untuk menghadapi risiko tertentu melalui akad (perikatan) yang sesuai dengan prinsip syariah".

Berdasarkan pengertian tersebut, asuransi syariah memiliki elemen penting yaitu usaha saling melindungi, dengan menggunakan dana/aset tabarru berdasarkan prinsip syariah. Kedudukan Dana Tabarru ini berbeda dengan premi dalam asuransi konvensional. Premi yang dibayarkan oleh pemegang polis menjadi milik perusahaan, dan atas pembayaran premi tersebut tertanggung atau pihak yang diasuransikan akan memperoleh manfaat apabila kejadian yang diperjanjikan 
terjadi. Dana tabarru merupakan kontribusi dari seluruh peserta asuransi yang ditujukan untuk saling menolong diantara mereka, yang pengelolaannya diserahkan kepada perusahaan asuransi.

Akad Tabarru dan dana Tabarru inilah yang menjadi salah satu pembeda antara mekanisme asuransi syariah dan konvensional. Selain akad Tabarru', untuk memenuhi tujuan komersial nya, perusahaan asuransi syariah dimungkinkan untuk menggunakan akad-akad lain yang bertujuan untuk memperoleh keuntungan, baik dari jasa mengelola dana maupun investasi dana. Dengan kata lain, dalam praktik asuransi syariah sebagai pelaku usaha, ada akad-akad komersial yang juga harus mematuhi prinsip syariah. Berbeda dengan asuransi syariah, dalam asuransi konvensional hanya terdapat satu jenis perjanjian yang bersifat komersial, yaitu perjanjian asuransi yang dituangkan dalam polis. Oleh karena itu, polis asuransi syariah sekurangnya memuat dua akad, yakni akad tabarru' (non komersial) dan akad tijarah (akad komersial) untuk mencapai tujuannya. Akad komersial yang digunakan sebagai dasar hubungan hukum bagi perusahaan asuransi syariah, adalah : (1) Akad Wakalah bil Ujrah; yaitu akad antara Peserta secara kolektif atau individu dengan Pengelola dengan tujuan komersial yang memberikan kuasa kepada pengelola sesuai kuasa atau wewenang yang diberikan, dengan imbalan berupa ûjrah (fee atau upah) (Ahmad Subagyo, 2009); (2) Akad Mudharabah; yaitu akad antara Peserta secara kolektif atau individu dengan Perusahaan dengan tujuan komersial yang memberikan kuasa kepada Perusahaan sebagai mudharib untuk mengelola investasi dana Tabarru' dan atau investasi Dana Peserta yang dibayarkan sesuai dengan ketentuan Polis; (3) Atau akad Mudharabah Musytarakah, yaitu akad antara Peserta secara kolektif atau individu dengan Perusahaan dengan tujuan komersial, yang memberikan kuasa kepada Perusahaan sebagai mudharib 
untuk mengelola Dana Tabarru' dan Dana Investasi Peserta, yang digabungkan dengan kekayaan Perusahaan, sesuai bagi hasil (nisbah) yang besarnya ditentukan berdasarkan komposisi investasi yang digabungkan dan telah disepakati sebelumnya.

Perbedaan antara akad dalam mekanisme asuransi konvensional dan asuransi syariah di atas, harus dijabarkan ke dalam klausulklausul dalam polis. Oleh karena itu, penerbitan pedoman polis akan sangat bermanfaat untuk mengarahkan perusahaan asuransi syariah dalam menerapkan prinsip-prinsip syariah. Selain menerbitkan pedoman polis, AASI terus mendorong sumber daya manusia dalam aktivitas asuransi syariah, khususnya agen penjual untuk memastikan bahwa prinsip-prinsip syariah ini dapat disampaikan dengan baik kepada masyarakat.

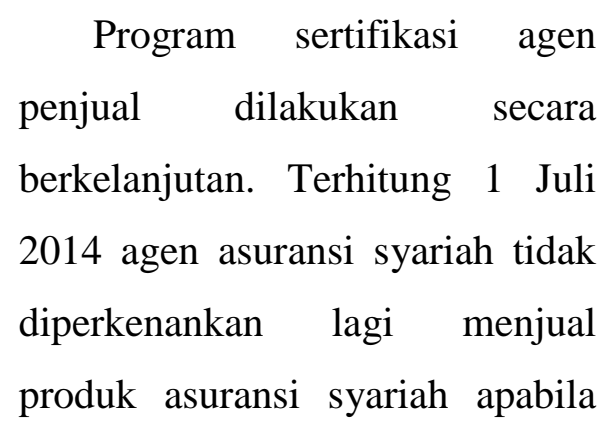

belum memiliki sertifikasi asuransi syariah. Ke dua upaya yang dilakukan oleh AASI ini saling melengkapi satu sama lain. Polis asuransi syariah yang sudah seragam dan sesuai dengan prinsip syariah memudahkan para agen penjual memasarkan produk asuransi syariah, sedangkan agen penjual yang sudah bersertifikasi diharapkan dapat memberikan jaminan bahwa produk yang ditawarkan sudah mematuhi prinsip syariah. Pemahaman terhadap prinsip syariah menjadi sangat relevan mengingat terdapat perbedaan yang mendasar antara asuransi konvensional dan syariah.

Sebelum diterbitkan pedoman polis asuransi syariah oleh AASI, dasar hukum penerbitan polis mengacu pada Fatwa Dewan Syariah Nasional (DSN) Nomor 21/DSN-MUI/X/2001 Tentang Pedoman Umum Asuransi Syariah, yang mengatur bahwa akad (perjanjian) antara perusahaan asuransi syariah dan peserta harus mengakomodasikan hal-hal sebagai berikut : (1) kontrak (akad) tidak mengandung gharar (penipuan); maysir (judi); riba; 
zhulm (penganiayaan), risywah (suap), barang haram dan maksiat; Kontrak harus jelas menyebutkan akad tabarru untuk kontribusi dari nasabah selaku partisipan (peserta) kepada perusahaan asuransi syariah (takaful), dan akad tijarah untuk pengelolaan dana tabarru. (2) Kontribusi yang diberikan oleh partisipan sebagai dana tabarru yang akan dikelola oleh perusahaan takaful. (3) Hak dan kewajiban peserta dan perusahaan. (4) Cara dan waktu pembayaran kontribusi. (5) Jenis akad tijarah

Pedoman polis yang dikeluarkan oleh AASI mengatur lebih rinci mengenai hak dan kewajiban para pihak, dan menerjemahkan bagaimana prinsip syariah dielaborasi dalam polis asuransi syariah. Sebagai bagian dari sistem keuangan syariah, kepatuhan terhadap prinsip syariah merupakan kewajiban bagi seluruh perusahaan asuransi syariah dalam menawarkan produknya. Secara konseptual, asuransi syariah bertumpu pada pembagian risiko (risk sharing) diantara para peserta berdasarkan prinsip kerjasama yang saling menguntungkan dan saling menolong (mutual cooperation) melalui kontribusi sukarela yang menjadi dana tabarru, dan selanjutnya dikelola oleh perusahaan asuransi syariah untuk kepentingan para peserta. Hal ini berbeda dengan konsep asuransi konvensional yang bertumpu pada pengalihan risiko dari peserta kepada perusahaan asuransi(Lastuti Abubakar, 2013:604.). Beberapa elemen yang dilarang dalam akad asuransi syariah, antara lain : (1) Gharar: ketidakpastian hak para pihak secara kontraktual yang sering menjadi sumber sengketa. Dalam asuransi konvensional unsur gharar(ketidakpastian/uncertainty ) ini dapat dilihat dari kedudukan para pihak, dimana satu pihak (perusahaan asuransi) mempunyai hak untuk mendapatkan keuntungan dari hasil investasi premi yang dibayarkan oleh tertanggung, namun di pihak lain, tertanggung tidak memiliki akses pada dana tersebut. (Ethica Institute, 2015) (2) Maysir : dalam 
asuransi syariah unsur spekulasi dalam kontrak asuransi dapat disimpulkan dari kewajiban tertanggung untuk membayar premi untuk mengharapkan jumlah yang lebih besar apabila terjadi kerugian, namun akan kehilangan premi yang dibayarkan apabila "kejadian yang belum tentu " tersebut tidak terjadi. (3) Riba : setiap kelebihan jumlah yang dikenakan yang tidak seimbang dengan kewajiban. Dalam asuransi konvensional, unsur riba ini diperoleh melalui dua cara yaitu : riba yang diperoleh secara langsung sebagai kelebihan atau selisih antara dalam pembayaran premi dengan pembayaran klaim asuransi, dan yang ke dua, riba tidak langsung yang diperoleh sebagai keuntungan atas investasi berbasis bunga yang dilakukan oleh perusahaan asuransi dalam mengelola premi asuransi.

Mengacu pada unsur-unsur yang dilarang dalam prinsip syariah tersebut, maka dapat disimpulkan beberapa perbedaan antara asuransi konvensional dan syariah yang harus diakomodasikan dalam polis.

Tabel 3.1. Perbedaan antara Asuransi Konvensional dan Asuransi Syariah

\begin{tabular}{|c|c|}
\hline Asuransi Konvensional & Asuransi Syariah \\
\hline $\begin{array}{l}\text { Kontrak asuransi konvensional } \\
\text { adalah kontrak yang murni } \\
\text { melibatkan } \\
\text { (uncertainty) }\end{array}$ & $\begin{array}{lr}\text { Kontrak asuransi } & \text { syariah } \\
\text { didasarkan pada kerjasama saling } \\
\text { menguntungkan } & \text { melalui } \\
\text { kontribusi peserta } & \end{array}$ \\
\hline $\begin{array}{l}\text { Perusahaan } \\
\text { melaksanakan kontrak asuransi } \\
\text { namanya sendiri }\end{array}$ & $\begin{array}{l}\text { Perusahaan mengelola dan } \\
\text { menginvestasikan premi } \\
\text { berdasarkan akad mudharabah , } \\
\text { dan peserta mempunyai } \\
\text { penyertaan dalam dana tabarru'. }\end{array}$ \\
\hline $\begin{array}{l}\text { Premi menjadi milik perusahaan } \\
\text { sebagai imbalan atas klaim yang } \\
\text { harus dibayar oleh perusahaan. }\end{array}$ & $\begin{array}{l}\text { Dana kontribusi merupakan dana } \\
\text { yang tidak dimiliki oleh } \\
\text { perusahaan, melainkan menjadi } \\
\text { dana untuk kerjasama saling } \\
\text { menolong (cooperative insurance } \\
\text { account) }\end{array}$ \\
\hline $\begin{array}{l}\text { Seluruh premi setelah dikurangi } \\
\text { dari biaya klaim merupakan } \\
\text { keuntungan perusahaan }\end{array}$ & $\begin{array}{l}\text { Seluruh kelebihan setelah } \\
\text { dikurangi, premi didistribusikan } \\
\text { diantara para peserta berdasarkan }\end{array}$ \\
\hline
\end{tabular}




\begin{tabular}{|c|c|}
\hline & $\begin{array}{l}\text { rasio kontribusi atau berdasarkan } \\
\text { metode yang disepakati. }\end{array}$ \\
\hline $\begin{array}{l}\text { Seluruh keuntungan investasi } \\
\text { akan menjadi milik perusahaan }\end{array}$ & $\begin{array}{l}\text { Keuntungan berbasis bagi hasil } \\
\text { dari investasi kontribusi, setelah } \\
\text { dikurangi bagian pengelola, } \\
\text { menjadi milik dana partisipan. }\end{array}$ \\
\hline $\begin{array}{l}\text { Perusahaan dan tertanggung } \\
\text { merupakan dua entitas yang } \\
\text { terpisah }\end{array}$ & $\begin{array}{l}\text { Perusahaan asuransi syariah dan } \\
\text { peserta adalah sama, yaitu } \\
\text { anggota dari dana yang dikelola, } \\
\text { untuk saling menanggung satu } \\
\text { sama lain terhadap kerugian. Para } \\
\text { partisipan bersama-sama berbagi } \\
\text { risiko (risk sharing) }\end{array}$ \\
\hline $\begin{array}{l}\text { Menyediakan perlindungan } \\
\text { terhadap risiko yang tidak dapat } \\
\text { ditentukan (kemungkinan rugi, } \\
\text { tidak rugi atau untung) }\end{array}$ & $\begin{array}{l}\text { Hanya menyediakan } \\
\text { perlindungan terhadap kerugian } \\
\text { yang nyata ( kemungkinan rugi) }\end{array}$ \\
\hline $\begin{array}{lll}\begin{array}{l}\text { Sisa kekayaan asuransi } \\
\text { dilikuidasi dipegang } \\
\text { perusahaan }\end{array} & \text { oleh } \\
& & \\
\end{array}$ & $\begin{array}{l}\text { Sisa kekayaan diserahkan untuk } \\
\text { amal saat likuidasi. }\end{array}$ \\
\hline
\end{tabular}

Sumber : diolah dari Ethica Institute, Understanding Takaful-Islamic Insurance, 2016

Selanjutnya, berdasarkan pada perbedaan subtansi di atas, maka dapat disimpulkan beberapa unsur esensialia yang harus terkandung dalam polis asuransi syariah, antara lain : (1) Asuransi syariah menawarkan proteksi berbasis prinsip syariah melalui kerjasama saling menolong (mutual cooperation). (2) Hubungan kontraktual antara perusahaan asuransi dan peserta berdasarkan itikad baik dimana ke dua belah pihak dalam kontrak membuka semua fakta material yang relevan tanpa ada keinginan untuk menipu, curang atau merugikan pihak lain.

Hubungan hukum berdasarkan 3 akad utama, yaitu Musyarakah diantara para peserta untuk dana Tabarru', Wakalah atau perwakilan antara perusahaan dengan peserta, dan Mudharabah antara peserta dengan pengelola dana. (4) Perusahaan asuransi dalam kapasitasnya sebagai pengelola dana tabbaru hanya bertanggung jawab dalam hal terbukti terjadi kelalaian pengelolaan oleh perusahaan. (5) Para pihak harus memenuhi 
kewajiban dalam kontrak, peserta asurasi dan pihak yang termasuk syarat-syarat yang tidak secara langsung berkaitan dengan sifat kerjasama dalam kontrak. (6) Perusahaan asuransi dapat memperoleh komisi atas jasa yang ditawarkan, namun demikian keuntungan yang diperoleh dari investasi dana berdasarkan akad mudharabah harus didistribusikan sesuai dengan porsi investasi masing-masing. (7) Dalam hal terjadi kerugian pada para peserta, maka perusahaan asuransi dapat menggantungkan pada kewajiban para peserta demi kepentingan para peserta. alternatif lainnya, menyebabkan kerugian dapat bermusyawarah sesuai prinsip syariah. (8) Dewan Pengawas Syariah harus mengawasi bahwa mekanisme asuransi syariah patuh pada prinsip syariah.

b) Substansi yang harus dimuat dalam polis standar untuk menjamin kepatuhan terhadap prinsip syariah.

Berdasarkan pedoman polis asuransi syariah yang diterbitkan oleh AASI, dengan mengacu pada regulasi yang berkaitan dengan aktivitas asuransi syariah, polis standar asuransi syariah wajib memuat substansi sebagaimana diuraikan dalam tabel di bawah ini.

Tabel 3.2. Klausul yang wajib dicantumkan dalam polis

(contoh asuransi jiwa) syariah.

\begin{tabular}{|c|c|c|c|}
\hline No & klausul & Rincian klausul & Keterangan klausul \\
\hline 1 & $\begin{array}{l}\text { Pembentukan } \\
\text { dana tabarru } \\
\text { untuk setiap } \\
\text { lini usaha }\end{array}$ & $\begin{array}{l}\text { dalam hal jumlah bilangan besar } \\
\text { untuk suatu lini usaha belum } \\
\text { memenuhi jumlah bilangan besar, } \\
\text { perusahaan dapat membentuk dana } \\
\text { tabarru'secara gabungan dari } \\
\text { beberapa lini usaha }\end{array}$ & $\begin{array}{lr}\text { Apabila dana } & \text { tabarru' } \\
\text { dibentuk } & \text { secara } \\
\text { gabungan } & \text { dari } \\
\text { beberapa } & \text { lini } \\
\text { usaha,maka } & \text { harus } \\
\text { disebutkan apakah lini } \\
\text { usaha sejenis } & \text { atau } \\
\text { keseluruhan } & \text { tanpa } \\
\text { membedakan } & \text { jenis } \\
\text { produk. } & \end{array}$ \\
\hline 2 & $\begin{array}{l}\text { Penggunaan } \\
\text { dana tabarru }\end{array}$ & $\begin{array}{ll}\text { a. } & \text { pembayaran santunan } \\
& \text { kepada Peserta } \\
\text { b. } & \text { pembayaran reasuransi } \\
\text { c. } & \text { pembayaran kembali Qardh } \\
\text { d. pengembalian Dana } \\
\\
\text { Tabarru' }\end{array}$ & \\
\hline 3 & $\begin{array}{l}\text { Pengembalian } \\
\text { dana tabarru }\end{array}$ & $\begin{array}{l}\text { a. pembatalan polis } \\
\text { b. penghentian polis }\end{array}$ & \\
\hline
\end{tabular}




\begin{tabular}{|c|c|c|}
\hline & & $\begin{array}{ll}\text { Peserta } & \\
\text { c. } & \text { Penghentian polis oleh } \\
& \text { Perusahaan } \\
\text { d. } & \text { Pembayaran } \\
& \text { Dana Tabarru, Kontribusi }\end{array}$ \\
\hline 4 & $\begin{array}{l}\text { Akad yang } \\
\text { digunakan }\end{array}$ & $\begin{array}{l}\text { a. akad Tabarru' } \\
\text { b. Akad Tijarah }\end{array}$ \\
\hline 5 & $\begin{array}{l}\text { Pembayaran } \\
\text { kontribusi dari } \\
\text { Peserta }\end{array}$ & $\begin{array}{l}\text { a. cara dan waktu pembayaran } \\
\text { kontribusi } \\
\text { b. cara pengajuan permintaan } \\
\text { pembayaran klaim } \\
\text { c. saat berlakunya asuransi } \\
\text { d. tenggang waktu } \\
\text { pembayaran kontribusi } \\
\text { e. periode perusahaan tidak } \\
\text { dapat meninjau ulang } \\
\text { keabsahan kontrak asuransi } \\
\text { f. bahasa yang dijadikan } \\
\text { acuan dalam sengketa } \\
\text { apabila menggunkana dua } \\
\text { bahasa }\end{array}$ \\
\hline 6 & $\begin{array}{l}\text { Hak dan } \\
\text { kewajiban } \\
\text { Peserta }\end{array}$ & $\begin{array}{ll}\text { a. } & \text { objek yang dikuasakan } \\
& \text { pengelolaannya } \\
\text { b. hak dan kewajiban peserta } & \text { secara kolektif /individu } \\
& \text { sebagai muwakkil (pemberi } \\
& \text { kuasa) } \\
\text { c. hak dan kewajiban } & \text { Perusahaan untuk } \\
& \text { menanggung kerugian } \\
\text { d. batasan kuasa atau } & \text { wewenang Perusahaan } \\
\text { e. besaran, cara dan waktu } \\
\text { pemotongan ujrah (fee). }\end{array}$ \\
\hline 7 & $\begin{array}{l}\text { Objek yang } \\
\text { dikuasakan } \\
\text { kepada } \\
\text { Perusahaan }\end{array}$ & $\begin{array}{l}\text { a. kegiatan administrasi } \\
\text { b. pengelolaan dana } \\
\text { c. pembayaran klaim } \\
\text { d. underwriting } \\
\text { e. pengelolaan portofolio } \\
\text { risiko } \\
\text { f. pemasaran } \\
\text { g. investasi }\end{array}$ \\
\hline 8 & $\begin{array}{l}\text { Hak } \\
\text { Perusahaan }\end{array}$ & $\begin{array}{l}\text { a. tidak berhak atas } \\
\text { memperoleh bagian hasil } \\
\text { investasi (akad wakalah bil } \\
\text { ujrah) } \\
\text { b. berhak memperoleh bagian } \\
\text { investasi ( akad }\end{array}$ \\
\hline
\end{tabular}




\begin{tabular}{|c|c|c|c|}
\hline & & $\begin{array}{l}\text { mudharabah/mudharabah } \\
\text { musytarakah) }\end{array}$ & \\
\hline 9 & $\begin{array}{l}\text { Klausul khusus } \\
\text { dalam akad } \\
\text { Mudharabah }\end{array}$ & $\begin{array}{l}\text { a. hak dan kewajiban Peserta } \\
\text { secara kolektif /individu } \\
\text { sebagai pemilik dana } \\
\text { (sahibul mal) } \\
\text { b. hak dan kewajiban } \\
\text { Perusahaan sebagai } \\
\text { pengelola dana (mudharib) } \\
\text { c. batasan wewenang yang } \\
\text { diberikan Peserta kepada } \\
\text { Perusahaan } \\
\text { d. bagi hasil (nisbah), cara dan } \\
\text { waktu pembagian investasi }\end{array}$ & \\
\hline 10 & $\begin{array}{l}\text { Klausul khusus } \\
\text { dalam akad } \\
\text { Mudharabah } \\
\text { Musytarakah }\end{array}$ & $\begin{array}{l}\text { a. hak dan kewajiban Peserta } \\
\text { secara kolektif/individu } \\
\text { b. hak dan kewajiban } \\
\text { Perusahaan sebagai } \\
\text { pengelola dana (mudharib) } \\
\text { c. batasan wewenang yang } \\
\text { diberikan Peserta kepada } \\
\text { Perusahaan } \\
\text { d. bagi hasil (nisbah), cara dan } \\
\text { waktu pembagian investasi }\end{array}$ & \\
\hline 11 & $\begin{array}{l}\text { Pemotongan } \\
\text { biaya }\end{array}$ & $\begin{array}{l}\text { melalui bagi hasil investasi } \\
\text { yang dilakukan diakhir atau } \\
\text { dibelakang }\end{array}$ & $\begin{array}{l}\text { Dengan cara hasil } \\
\text { investasi yang } \\
\text { diperoleh dikurangkan } \\
\text { terlebih dahulu dengan } \\
\text { biaya2 dan setelahnya } \\
\text { diperhitungkan bagi } \\
\text { hasil kepada Peserta }\end{array}$ \\
\hline 12 & Biaya-biaya & $\begin{array}{l}\text { Biaya yang dikenakan kepada } \\
\text { Peserta }\end{array}$ & \\
\hline 13 & Akad Tijarah & $\begin{array}{l}\text { a. Akad Wakalah bil Ujrah } \\
\text { b. Akad Mudharabah }\end{array}$ & $\begin{array}{l}\text { Pengelolaan risiko dan } \\
\text { pengelolalan investasi } \\
\text { Dana Tabarru' }\end{array}$ \\
\hline 14 & $\begin{array}{l}\text { Surplus } \\
\text { underwriting }\end{array}$ & $\begin{array}{l}\text { a. seluruhnya ditambahkan ke } \\
\text { dalam Dana Tabarru' } \\
\text { b. sebagian ditambahkan ke } \\
\text { dalam Dana Tabarru', } \\
\text { sebagian dibagikan kepada } \\
\text { Peserta } \\
\text { c. Sebagaian ditambahkan ke } \\
\text { dalam Dana Tabarru', } \\
\text { sebagian dibagikan kepada } \\
\text { Peserta dan Perusahaan. } \\
\text { Dalam hal masih terdapat } \\
\text { Qardh dalam kewajiban }\end{array}$ & $\begin{array}{lr}\text { Syarat menerima } \\
\text { surplus underwriting : } \\
\text { telah membayar } \\
\text { kontribusi, } r \text { tidak } \\
\text { sedang dalam proses } \\
\text { penyelesaian klaim, } \\
\text { tidak pernah menrima } \\
\text { pembayaran klaim } \\
\text { yang melebihi jumlah } \\
\text { kontribusi yang } \\
\text { dialokasikan ke dana } \\
\text { tabarru, dan tidak }\end{array}$ \\
\hline
\end{tabular}




\begin{tabular}{|c|c|c|c|}
\hline & & $\begin{array}{lr}\text { Dana Tabarru' } & \text { atau } \\
\text { pembagian } & \text { surplus } \\
\text { underwriting, } & \text { perusahaan } \\
\text { dilarang } & \text { melakukan } \\
\text { pembagian } & \text { surplus } \\
\text { underwriting. } & \end{array}$ & $\begin{array}{l}\text { menghentikan polis. } \\
\text { Pilihan pembagian } \\
\text { surplus underwriting } \\
\text { tidak dapat diubah } \\
\text { sampai berakhir polis } \\
\text { Peserta berupa badan, } \\
\text { maka pembagian } \\
\text { surplus underwriting } \\
\text { akan diterima badan } \\
\text { surplus underwriting } \\
\text { berdasarkan aktiva } \\
\text { dalam kas (cash basis) }\end{array}$ \\
\hline 15 & $\begin{array}{l}\text { Ketentuan } \\
\text { Qardh }\end{array}$ & $\begin{array}{l}\text { a. dana Tabarru' tidak cukup } \\
\text { membayar santunan/klaim } \\
\text { kepada Peserta } \\
\text { b. pengembalian Qardhkepada } \\
\text { Perusahaan dilakukan dari } \\
\text { surplus underwriting atau } \\
\text { Dana Tabarru. }\end{array}$ & \\
\hline \multirow[t]{3}{*}{16} & Pengaturan & a. musyawarah untuk mufakat & \multirow{3}{*}{$\begin{array}{l}\text { Pemilihan forum harus } \\
\text { dilakukan dengan } \\
\text { mempertimbangkan } \\
\text { kompetensi, baik } \\
\text { relatif raupun } \\
\text { absolut. }\end{array}$} \\
\hline & Perselisihan & b. Badan Mediasi Asuransi & \\
\hline & & $\begin{array}{l}\text { c. Badan Arbitrase Syariah } \\
\text { Nasional (BASYARNAS) } \\
\text { d. Pengadilan Agama } \\
\text { e. Pengadilan Negeri }\end{array}$ & \\
\hline & Penutup & $\begin{array}{l}\text { Selain hal yang diatur dalam polis, } \\
\text { maka berlaku ketentuan perundang- } \\
\text { undangan } \\
\text { bertentangan } \\
\begin{array}{l}\text { syariah. } \\
\text { syang }\end{array}\end{array}$ & \\
\hline & Keterangan & $\begin{array}{l}\text { Polis wajib mengacu pada pedoman } \\
\text { polis yang dikeluarkan oleh AASI }\end{array}$ & $\begin{array}{l}\text { Pedoman polis } \\
\text { terdiri dari asuransi } \\
\text { jiwa syariah dan } \\
\text { asuransi } \\
\text { syariah. }\end{array}$ \\
\hline
\end{tabular}

Sumber : Pedoman Polis Asuransi Jiwa berdasarkan prinsip syariah

AASI 2014

Berdasarkan pedoman yang harus dimasukkan dalam polis dan dikeluarkan oleh AASI tersebut, diperhatikan oleh perusahaan perlu diberikan beberapa catatan asuransi syariah, yaitu : (1) tentang praktik pembuatan polis Perusahaan asuransi syariah perlu standar, khususnya klausul yang melihat Peraturan Otoritas Jasa 
Keuangan (POJK) Nomor kewajiban penyesuaian polis 1/POJK.07/2013 Tentang seluruh asuransi syariah dengan Perlindungan Konsumen Sektor Jasa Keuangan, khususnya berkaitan dengan implementasi prinsip perlindungan konsumen yang diatur dalam Pasal 2 POJK, antara lain prinsip transparansi. Berdasarkan Pasal 4 POJK tersebut perusahaan asuransi syariah wajib menyediakan dan/atau menyampaikan informasi mengenai produk dan/atau layanan yang akurat, jujur, jelas, dan tidak menyesatkan. Berkenaan dengan polis standar, maka informasi tersebut dapat disampaikan pada saat perusahaan menyampaikan polis pada Peserta atau pemegang polis.

Mengingat polis standar adalah bukti adanya perjanjian diantara Perusahaan dan Peserta, diperlukan pemahaman yang komprehensif terhadap seluruh ketentuan yang berlaku bagi asuransi syariah, sepanjang tidak bertentangan dengan prinsip syariah. (3) Asosiasi Asuransi Syariah Indonesia (AASI) sebagai organisasi yang menerbitkan pedoman perlu menindaklanjuti pedoman ini dengan melakukan pemeriksaan dan kajian terhadap standar polis yang sudah dilakukan oleh perusahaan asuransi syariah dan menyatakan bahwa polis sudah sesuai. (4) Asosiasi perlu melakukan kordinasi dengan OJK terkait standarisasi polis ini, khususnya menyangkut pelanggaran dan ketidakpatuhan terhadap prinsip syariah yang terkandung dalam polis.

\section{c) Pengaturan Standarisasi Polis Asuransi Syariah}

Tidak ditemukan regulasi yang mengatur kewajiban tentang standar polis asuransi syariah. AASI menerbitkan pedoman polis asuransi syariah baik untuk asuransi jiwa dan umum pada bulan Mei 2014, dan sejak bulan Januari 2015 seluruh polis asuransi syariah sudah mengikuti pedoman yang dikeluarkan oleh AASI. Dalam praktik, memang ditemukan perusahaan asuransi syariah yang cukup rinci memuat ketentuan dalam polis, namun juga menemukan perusahaan asuransi syariah yang membuat 
standar polis yang sederhana.

Polis asuransi Jiwa Syariah

Prudential misalnya, memuat 19

pasal dengan lampiran yang

lengkap tentang ketentuan

tambahan atau ketentuan khusus, sementara itu polis asuransi Jiwa

Blife Syariah Unit Link memuat

25 Pasal, namun substansinya memuat klausul-klausul pokok yang harus ada dalam polis. Permasalahan hukumnya, bukan pada banyak sedikitnya klausul dalam polis, melainkan apakah seluruh prinsip-prinsip asuransi syariah yang membedakan nya dengan asuransi konvensional sudah diakomodasikan secara baik dalam polis standar (Hasil Penelitan Lastuti Abubakar dkk, 2014).

Berdasarkan hasil penelitian sebelum implementasi polis standar yang diterbitkanoleh AASI, tim Peneliti dapat mencatat beberapa hal yakni : (a) Masingmasing perusahaan menggunakan istilah dan penyebutan yang tidak baku. Kontribusi peserta masih disebut sebagai premi di dalam polis Blife. (b) Dalam hak dan kewajiban Peserta dan Perusahaan, lebih banyak memuat kewajiban peserta dan hak Perusahaan, lazimnya kontrak standar. (c) Belum tampak transparansi yang diharapkan menjadi ciri polis asuransi syariah. (d) Kepatuhan terhadap prinsip syariah belum dijabarkan dengan bahasa yang lugas, sehingga sulit membedakan polis asuransi syariah dengan konvensional, kecuali penyebutan dana tabarru dan akad wakalah bil ujrah (prudential). Berdasarkan perbandingan ke dua polis, polis asuransi jiwa syariah prudential memuat lebih banyak substansi yang diharuskan dalam pedoman AASI.

\section{d) Peran Otoritas Jasa Keuangan (OJK) dan AASI dalam Program Standarisasi Polis Asuransi Syariah \\ Dalam program standarisasi} polis asuransi syariah terdapat dua institusi yang memegang peran penting disamping institutsi lainnya, yakni OJK dan AASI sebagai asosiasi yang menaungi asuransi syariah, yaitu otoritas Jasa Keuangan (OJK) dan Asosiasi Asuransi Syariah Indonesia (AASI) sebagai 
organisasi yang menaungi industri Asuransi Syariah.

\section{1) Fungsi Pengaturan dan Pengawasan oleh Otoritas Jasa Keuangan (OJK)}

Berdasarkan Pasal 5 Undangundang Nomor 21 Tahun 2011 Tentang Otoritas Jasa Keuangan, OJK mempunyai fungsi menyelenggarakan sistem pengaturan dan pengawasan yang terintegrasi terhadap keseluruhan kegiatan di dalam sektor jasa keuangan. Fungsi ini tidak dapat dilepaskan dari tujuan pembentukan OJK, yang salah satunya mampu melindungi kepentingan konsumen dan masyarakat (Pasal 4 UU Nomor 21 Tahun 2011 Tentang Otoritas Jasa Keuangan ). Apabila dikaitkan dengan pentingnya standarisasi polis yang bertujuan untuk memastikan kepatuhan terhadap prinsip syariah, maka OJK berperan memberikan landasan hukum yang kokoh bagi kegiatan standarisasi polis dan melakukan pengawasan terhadap implementasinya guna melindungi kepentingan konsumen dan masyarakat. Oleh karena itu, pedoman polis yang sudah diterbitkan oleh AASI tetap memerlukan tindak lanjut berupa wadah dalam bentuk peraturan OJK. Selain memberikan landasan hukum, OJK juga mempunyai peran mengawasi aktivitas jasa keuangan, termasuk asuransi syariah. Berkaitan dengan pengawasan, OJK memiliki kewenangan untuk melakukan pemeriksaan dalam hal terjadi pelanggaran administratif dan perdata, serta penyidikan apabila terjadi pelanggaran pidana. (Pasal 8 dan 9 UU Nomor 21 Tahun 2011 tentang Otoritas Jasa Keuangan). Fungsi pengawasan ini akan berjalan optimal, apabila OJK menjalankan penegakan hukum (law enforcement) berdasarkan ketentuan yang berlaku. OJK memiliki keleluasaan untuk bekerja sama dengan asosiasi dan industri, bahkan dengan institusi akademis untuk menghasilkan fungsi regulasi, pengawasan dan pembinaan yang optimal. Kerjasama OJK dan AASI dalam menentukan kebijakan di bidang asuransi syariah sangat diperlukan.
2) Peran Asosiasi Asuransi Syariah Indonesia (AASI) 
Asosiasi Asuransi Syariah Indonesia (AASI) merupakan organisasi yang anggotanya adalah pelaku industri asuransi syariah, sehingga dianggap memahami aktivitas dan kebutuhan pelaku industri asuransi syariah. Selain itu, AASI mengemban misi antara lain memasyarakatkan asuransi syariah, membina para anggota untuk lebih meningkatkan kapasitas produksi dan standar pelayanan berbasis syariah serta meningkatkan kemampuan teknis dan manajerial anggota (visi dan misi AASI 2015). Berdasarkan hal tersebut, Asosiasi mempunyai kemampuan yang cukup untuk menetapkan standar dan pedoman yang tepat bagi perusahaan asuransi syariah dan mendorong para pelaku untuk mengimplementasikan pedoman tersebut dalam praktik. Asosiasi juga memahami kendala untuk mengembangkan asuransi syariah, sehingga lebih mudah bagi asosiasi untuk menyediakan kebutuhan infrastruktur legal dan teknis dalam rangka mendorong kepatuhan terhadap prinsip syariah. Sejauh ini, asosiasi telah menerbitkan pedoman polis yang akan berlaku serentak bagi seluruh perusahaan asuransi syariah per Januari 2015.

Standarisasi polis bagi seluruh perusahaan asuransi syariah tidak saja membutuhkan waktu, namun juga memerlukan kecermatan dan pendampingan oleh Asosiasi, mengingat hambatan sumber daya manusia. Berdasarkan penelitian sebelumnya (Hasil penelitian Lastuti dkk, 2014), AASI mengakui hambatan ketersediaan SDM yang kompeten dalam rangka optimalisasi asuransi syariah sebagai salah satu institusi keuangan. Permasalahan utama bagi SDM asuransi syariah adalah belum optimalnya pemahaman yang komprehensif tentang prinsip syariah yang harus dijelaskan kepada konsumen. Upaya Asosiasi untuk mewajibkan sertifikasi agen asuransi syariah merupakan upaya simultan untuk mempercepat kesiapan industri asuransi syariah untuk memperoleh kepercayaan masyarakat, meningkatkan 
pertumbuhan dan mendorong penjualan produk asuransi syariah. (Wawancara dengan Ketua Umum AASI Bapak M. Shaifie Zein dan Wakil Ketua Umum Bidang Tehnik AASI Ibu Srikandi Utami pada tanggal 23 Mei 2014 di Jakarta ). AASI berharap melalui sertifikasi agen dan standarisasi polis, industri asuransi syariah dapat mengimplementasikan kepatuhan terhadap prinsip syariah (sharia compliance) sebagai bentuk perlindungan terhadap masyarakat dan mewujudkan visinya untuk menjadikan asuransi syariah sebagai pilihan utama dalam berasuransi.

\section{Simpulan}

1) Secara konseptual, asuransi syariah bertumpu pada pembagian risiko (risk sharing) diantara para peserta berdasarkan prinsip kerjasama yang saling menguntungkan dan saling menolong (mutual cooperation) melalui kontribusi sukarela yang menjadi dana tabarru, dan selanjutnya dikelola oleh perusahaan asuransi syariah untuk kepentingan para peserta. Hal ini berbeda dengan konsep asuransi konvensional yang bertumpu pada pengalihan risiko dari peserta kepada perusahaan asuransi dengan pembayaran premi yang menjadi milik perusahaan.

2) Perusahaan Asuransi Syariah wajib memastikan kepatuhan terhadap prinsip syariah sebagai pembeda dengan asuransi konvensional. Aktivitas asuransi syariah tidak boleh bertentangan dengan prinsip syariah yang melarang gharar, maysir dan riba. Akad yang digunakan dalam polis terdiri akad tabarru bagi pengelolaan dana tabarru yang akan digunakan untuk saling tolong diantara para peserta dan akad komersial (tijarah) untuk pengelolaan risiko dan pengelolalan investasi Dana Tabarru' dengan menggunakan akad wakalah bil ujrah atau mudharabah. Prinsip-prinsip syariah tersebut wajib dimasukkan 
dalam polis asuransi sebagai perjanjian antara perusahaan asuransi syariah dan nasabah.

3) Asosiasi Asuransi Syariah Indonesia (AASI) telah menerbitkan pedoman standar polis asuransi syariah sebagai upaya untuk memastikan kepatuhan terhadap prinsip syariah dalam rangka memberikan perlindungan hukum yang optimal bagi nasabah.

4) Selain AASI yang berperan dalam mengoptimalkan penggunaan polis standar dan sertifikasi profesi (sumber daya manusia), maka Otoritas Jasa Keuangan berperan untuk memberikan landasan hukum yang kokoh serta melakukan pengawasan terhadap pelanggaran regulasi dan kesepakatan yang dituangkan dalam polis yang dilakukan oleh perusahaan asuransi syariah.

\section{Daftar Rujukan}

Ahmad Subagyo (2009), Kamus Istilah Ekonomi Islam, PT Elex Media Komputindo, Jakarta.

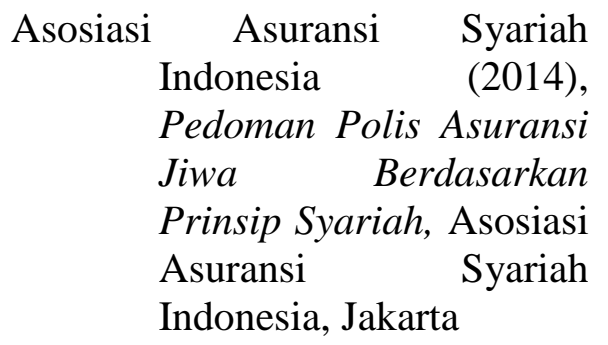

Ernst \& Young (2014), Global Takaful Insights 2014 Market Updates-Growth Momentum Continues

Ethica Institute (2015), Understanding TakafulIslamic Insurance, Institute of Islamic Finance

Malaysia International Islamic Financial Centre (2014), Global TakafulContinues Unbroken Double Digit Growth

Lastuti Abubakar,dkk (2013), Analisis Terhadap Penerapan Prinsip Mutual Cooperation dalam Mekanisme Takaful (Asuransi Syariah) dalam Peran Hukum Dalam Pembangunan di Indonesia-Kenyataan, Harapan, dan Tantangan, Rosda, Bandung

Lastuti Abubakar dkk (2014), Hasil Penelitian "Urgensi Sertifikasi Kelembagaan Asuransi Syariah (Takaful) dalam Rangka Perlindungan Nasabah",Bandung

Otoritas Jasa Keuangan (2015), Roadmap Industri 
Keuangan Non Bank Syariah 2015-2019

Ronny Hanitijo Soemitro (1988), Metodologi Penelitian Hukum dan Jurimetri, Ghalia Indonesia, Jakarta.

Undang-undang Nomor 21 Tahun 2011 Tentang Otoritas Jasa Keuangan

Undang-undang Nomor 40 Tahun 2014 Tentang Perasuransian.

Peraturan Pemerintah Nomor 81 Tahun 2008 tentang Perubahan Ketiga Atas Peraturan Pemerintah Nomor 73 Tahun 1992 Tentang Penyelenggaraan Usaha Perasuransian

Peraturan Otoritas Jasa Keuangan (POJK) Nomor 1/POJK.07/2013 Tentang Perlindungan Konsumen Sektor Jasa Keuangan 